\title{
Aandacht voor de NVMO-cursussen 2003
}

De Commissie Professionalisering Docenten (CPD) coördineert één van de beleidsprioriteiten van de NVMO, te weten de onderwijskundige professionalisering van docenten bij medische opleidingen. In dat kader beveelt de CPD u de volgende NVMO-cursussen dan ook van harte aan:

\section{Toetsing van medische competentie}

Deze cursus is bedoeld voor degenen, die onderwijs geven, coördineren of ontwikkelen en in dat kader te maken hebben met toetsing van medische competentie. De cursus beoogt de deelnemers inzicht te geven in: functies van toetsing, methoden van toetsing, samenstellen van toetsen, programmeren en organiseren van toetsen, onderwijskundige waarde van toetsing, de haalbaarheid van toetsing en tot slot psychometrische begrippen.

\section{Datum en plaats}

10 oktober in Utrecht en 23-24 oktober in Woudschoten.

\section{Docenten}

Prof. dr. C.P.M. van der Vleuten, psycholoog, hoogleraar Onderwijskunde en voorzitter van de Capaciteitsgroep Onderwijsontwikkeling en Onderwijsresearch, Faculteit Geneeskunde, Universiteit Maastricht.

Dr. L.W.T. Schuwirth, arts, medewerker van de Capaciteitsgroep Onderwijsontwikkeling en Onderwijsresearch, Faculteit Geneeskunde, Universiteit Maastricht.

\section{Kosten}

De kosten van deze driedaagse cursus bedragen $€ 900$ (incl. de overnachting op 23 oktober).

\section{Vaardigheidstraining}

Deze cursus is bedoeld voor docenten en organisatoren, die betrokken zijn of worden bij vaardigheidsonderwijs in gezondheidszorgopleidingen. $\mathrm{Na}$ het volgen van deze cursus is de deelnemer in staat de belangrijkste principes van het vaardigheidsonderwijs toe te passen in de eigen werksituatie.

\section{Datum en plaats}

31 oktober in Maastricht en 28 november in Nijmegen.

\section{Docenten}

Dr. J. van Dalen, psycholoog, coördinator Onderwijs Communicatievaardigheden, Faculteit Geneeskunde, Universiteit Maastricht (cursuscoördinator).

Drs. L. Fluit, arts/onderwijskundige, stafmedewerker Onderwijs Geneeskunde, UMC St Radboud, Nijmegen.

\section{Kosten}

De kosten van deze tweedaagse cursus bedragen $€ 500$.

\section{Onderzoek van medisch onderwijs}

Deze cursus is bedoeld voor docenten en onderwijskundigen die ervaring willen opdoen in onderzoek van medisch onder- 
wijs, of hun ervaring willen uitbreiden. De cursus beoogt deelnemers in staat te stellen zelfstandig een onderzoek over een medisch onderwijskundig onderwerp op te zetten en uit te voeren. Eerst worden enkele gesimuleerde onderzoeken doorgenomen, waarbij diverse onderzoeksdesigns en onderdelen van onderwijskundig onderzoek de revue passeren. Vervolgens worden de ideeën van de cursisten over hun eigen onderzoeksvoorstel besproken. Het verdere vervolg van de cursus geschiedt aan de hand van eigen onderzoek van de cursisten. Daarbij komt het verzamelen en analyseren van onderzoeksdata aan de orde, alsmede de verslaglegging.

\section{Datum en plaats}

19 november in Egmond aan Zee (voorafgaand aan NVMO-congres), daarna in 2004 op 15 januari en 4 november in Utrecht.

\section{Docenten}

Prof. dr. A.J.J.A. Scherpbier, arts, wetenschappelijk directeur Onderwijsinstituut, Faculteit Geneeskunde, Maastricht (cursuscoördinator).

Dr. ir. A.M.M. Muijtjens, statisticus, Faculteit Geneeskunde, Maastricht.

\section{Kosten}

De kosten van deze driedaagse cursus bedragen $€ 750$ (excl. de overnachtingskosten in Egmond vóór het NVMO-congres).

\section{Co-assistentschappen: onderwijs in de klinische fase}

Deze cursus is bedoeld voor al degenen, die betrokken zijn bij de uitvoering en/of de ontwikkeling van het onderwijs in de klinische fase, zowel in de academische ziekenhuizen als in de geaffilieerde ziekenhuizen. De cursus beoogt de deelne- mers bewust te maken van het specifieke karakter van het onderwijs in de klinische fase van de opleiding geneeskunde. De cursus richt zich zowel op het specifieke karakter als op de veranderingen die zich momenteel in alle opleidingen geneeskunde voltrekken in deze fase.

\section{Datum en plaats}

19 november in Egmond aan Zee (voorafgaand aan NVMO-congres).

\section{Docenten}

Prof. dr. P.M.J. Stuyt, internist, directeur Onderwijsinstituut, UMC St Radboud, Nijmegen (cursuscoördinator).

Dr. J.W. Briët, gynaecoloog en onderwijscoördinator, Deventer Ziekenhuis, Faculteit der Medische Wetenschappen, Groningen.

Prof. dr. G.G.M. Essed, gynaecoloog, hoogleraar Methodiek van Klinisch Onderwijs, Faculteit Geneeskunde, Universiteit Maastricht.

\section{Kosten}

De kosten van deze cursus bedragen $€ 300$ (excl. de overnachtingskosten in Egmond vóór het NVMO-congres).

\section{Effectief doceren}

Deze cursus is bedoeld voor docenten geneeskunde, die hun onderwijssessie beter willen structureren en uitvoeren en die feedback willen geven, maar ook ontvangen. In de cursus wordt aandacht besteed aan: het doel van effectief doceren, de structuur van een onderwijssessie, het belang van verbale en non-verbale elementen, enkele regels voor feedback.

\section{Datum en plaats}

19 november in Egmond aan Zee (voorafgaand aan NVMO-congres). 


\section{Docenten}

Dr. J. Cohen-Schotanus, hoofd afdeling Onderwijsontwikkeling en Kwaliteitszorg, Onderwijsinstituut, Faculteit der Medische Wetenschappen, Groningen.

Drs. R. Venekamp, Vakgroep Chirurgie, Academisch Ziekenhuis Groningen.

\section{Kosten}

De kosten van deze cursus bedragen $€ 250$ (excl. de overnachtingskosten in Egmond vóór het NVMO-congres).

\section{Informatie}

Voor informatie over deze cursussen en inschrijvingen kunt $\mathrm{u}$ terecht bij:

Mw. L.(Lydia) Boonekamp, tel. 030-253 8212,

l.boonekamp@med.uu.nl. 